\section{EREM 73/1}

Journal of Environmental Research, Engineering and Management Vol. 73 / No. 1 / 2017 pp. 8-19
Subjective Reasons for Littering: A Self-serving Attribution Bias as Justification Process in an Environmental Behaviour Model

Received 2017/06
Accepted after revision 2017/07

\title{
Subjective Reasons for Littering: A Self-serving Attribution Bias as Justification Process in an Environmental Behaviour Model
}

\section{Ralph Hansmann}

ETH Zurich (Swiss Federal Institute of Technology Zurich), Department of Environmental

Systems Science (D-USYS) Transdisciplinarity Lab (TdLab), Zürich, Switzerland

\section{Nora Steimer}

IGSU (IG saubere Umwelt) (Interest Group for a Clean Environment) Zurich, Switzerland

\section{Corresponding author: ralph.hansmann@env.ethz.ch}

Ralph Hansmann, ETH Zurich, Department of Environmental Systems Science (D-USYS), Transdisciplinarity Lab (TdLab), ETH Zurich CHN K42.1, Universitätsstrasse 22, CH-8092 Zürich, Switzerland

Subjective causal explanations for littering of waste are investigated through a questionnaire-based survey $(\mathrm{N}=147)$. Participants were asked if they littered waste in the past, and if so why. They were also asked why they think some other people litter. The majority of the participants (71\%) admitted having littered in the past. An analysis of the perceived reasons for littering showed significant differences in the reasons provided for their own littering as compared with other people's littering. The differences found were in line with previous research demonstrating a self-serving bias in intrapersonal as compared with interpersonal attributions. One's own littering is often justified by external causes, for example, shortcomings in the infrastructure, such as missing or filled garbage cans, whereas negative personal attributions, such as ignorance, naivety, and convenience, are most commonly considered to cause littering by others. The findings are discussed with reference to the integrative model of justified behaviour (MJB) (Hansmann and Steimer, 2015), which covers a broad range of factors including attitudes, norms, knowledge, restrictions and options, habit formation, and evaluative processes of justification as determinants of behavioural 
decision-making. Implications for environmental management and for the design of anti-littering campaigns and environmental education are discussed.

Keywords: littering, self-serving bias, attribution, justification, habit, behaviour model.

\section{Introduction}

The littering of waste in urban and natural settings reduces the aesthetic and ecological quality of the environment (Berger and Sommerhalder, 2011, Crabb, 2014). Littering is an annoying behaviour that causes high and avoidable costs and efforts for cleaning-up. A considerable amount of research has been devoted to the investigation of a broad range of measures for counteracting littering through environmental management and design and environmental education activities, such as organisation of clean-up days and conducting public anti-littering campaigns (de Kort et al., 2008, Durdan et al., 1985, Hansmann et al., 2015, Hansmann and Scholz, 2003, Hansmann and Steimer, 2016, Horsley, 1988, Reich and Robertson, 1979, Reiter and Samuel, 1980). However, the littering problem has persisted and in connection with a trend towards growing urban populations and more consumption outdoors (e.g., takeaway meals, beverages), it even became worse in some places in the recent years. However, while cultural and societal changes constitute macro trends that may facilitate littering, it remains a problematic behaviour displayed by individuals in the psychological field of particular situations (Hansmann and Steimer, 2015, Schultz et al., 2013). Hence, littering represents a problem of behavioural decision-making of individuals. This has been acknowledged in various previous studies relating measures for counteracting littering to psychological considerations of the learning theory (Keenan, 1996) and existing environmental behaviour models, such as the theory of planned behaviour (Ajzen, 1991, Hansmann, 2012) or the focus theory of normative conduct (Cialdini et al., 1990, Reno et al., 1993).

However, so far no study has asked litterers straightforwardly for the reasons that make them litter. This is unfortunate, because knowing more about the subjectively perceived reasons for littering seems crucial for understanding the cognitive and motivational processes connected to this problematic behaviour on the background of psychological theories on intra- and in- terpersonal attributions (Aronson et al., 2003, Heider, 1958, Kelley, 1973). Subjectively perceived reasons for littering may correspond with actual causes and could, thus, point towards options for tackling and counteracting the littering problem. This is true even though previous research has shown that self-attributions - as well as interpersonal attributions for behaviour of others should not be taken by face value. The stated reasons perceived by laymen do not always reveal the actual behaviour causes, as they tend to be biased to some extent (Jones et al., 1972, Watson, 1982). A well-known tendency in this regard is the so-called self-serving bias in causal attributions (Larson, 1977, Meyer and Försterling, 1993). This bias consists in a tendency of actors towards self-referential personal attributions for their positive behaviours and successful performances versus more situational attributions for own failures, mishaps, negative behaviours, and on the contrary in more situational attributions of observers for the success of others and rather personal attributions for others' failures, mishaps, and negative behaviours (Malle, 2006). In particular, in situations with a high level of threat to the self, actors display such a self-serving bias in causal attribution (Campbell and Sedikides, 1999). Assuming that engagement in morally wrong behaviours entails a high level of threat to the self, a particularly strong self-serving bias may exist in attributions for socially disapproved behaviours such as littering.

According to the neutralization theory by Sykes and Matza (1957), posterior explanations ( $\approx$ causal attributions) for own violations of social norms may represent rationalisations, which aim to justify the norm violation to protect the self from self-blame and being blamed by others. Justification processes may, thus, be a factor accounting for differences between self-attributions and attributions for the behaviour of other persons. According to the neutralization theory, a self-serving bias attributing one's own littering rather to situational causes could serve as justification protecting litterers from 
self-blame and being blamed by others. As compared with such intrapersonal attributions, littering by others may be explained to a larger extent by (negative) personal factors.

The existence of defence mechanisms against blame from others refers to the diametrically contrary process of accusing (offending) others for their misconduct. Thus, attributions for norm violations by others may reflect accusations in as much as attributions for one's own norm-violations represent justifications of the self. Considered on the background of the social comparison theory (Festinger, 1954), both justifying oneself and accusing others are identical in the effect to enhance the self in (moral) social comparison with others.

Psychological processes of justification have since long been investigated in the domain of criminology (Copes, 2003, Costello, 2000, Sykes and Matza, 1957). Since the 1990s, justification processes have also been investigated as a facilitating factor of environmentally negative behaviours and, thus, proved helpful to explain inconsistencies between environmental attitudes and behaviour (Diekmann and Preisendörfer, 1992, Fritsche, 1999, Hansmann et al., 2006, Schahn et al., 1995). These findings suggest that supplementary to subjective norms, perceived behavioural control, and behaviour intentions which are considered in the theory of planned behaviour (Ajzen, 1991, Armitage and Conner, 2001), processes of justification should be taken into account to better understand, explain and predict environmental behaviour.

Hansmann and Steimer (2015) accordingly developed an integrative model of justified behaviour (MJB), which covers, combines and integrates processes postulated by both the neutralization theory and the theory of planned behaviour and further concepts (Figure 1). The investigation of subjective explanations of litterers for their own past littering and the comparison of these intrapersonal attributions with interpersonal attributions for the littering of others will illustrate how processes of justification postulated within the MJB operate. Apart from justifications, personal norms and attitudes, social norms and group dynamics, knowledge and competencies and external restrictions and options determine environmental behaviour according to the MJB. Finally, habits of behaviour can develop according to the MJB if a certain behaviour has been displayed "successfully" several times. It should be noted in this regards that the primary or main function of waste disposal is to get rid of waste and that littering can in fact be deemed successful with reference to this goal, so that negative littering habits may easily develop, if no negative

Fig. 1

Schematic depiction of the model of justified behaviour (MJB) extended by processes of interpersonal attributions and evaluations of the behaviour of others (adapted from Hansmann and Steimer, 2015)

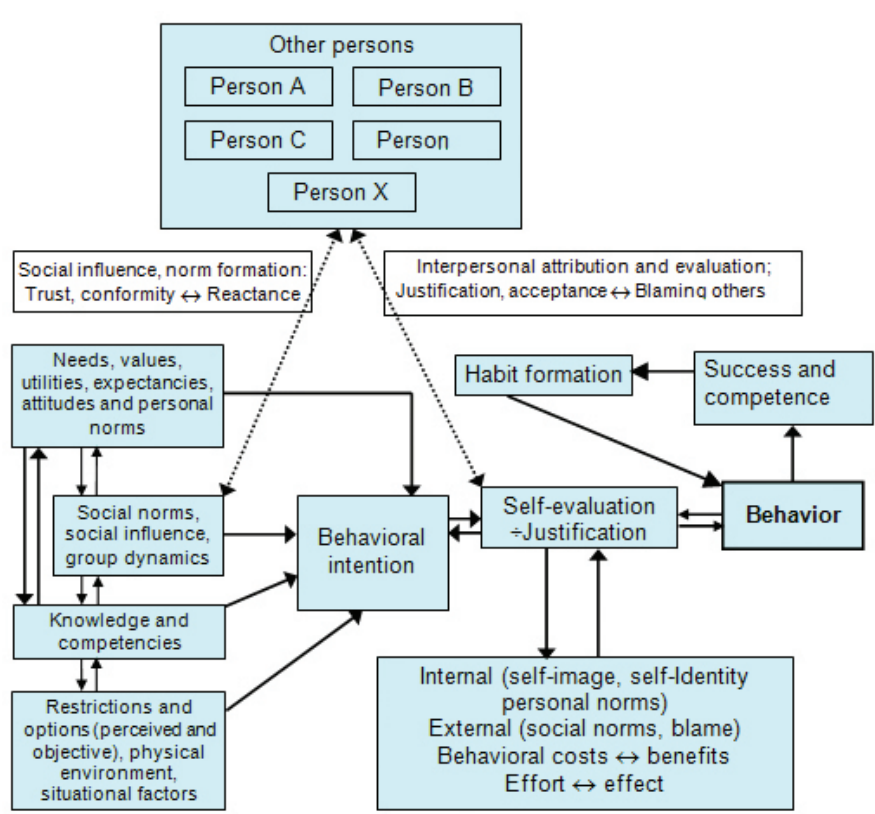


sanctions or consequences are experienced. If a negative behaviour such as littering is then displayed habitually, the behavioural decision-making is not highly conscious any more, which poses specific problems for changing it (cf. Dahlstrand and Biel, 1997, Lewin, 1951).

In this study, the stated subjective reasons of litterers for their own littering will be investigated to substantiate and further develop the MJB, and derive corresponding recommendations for counteracting littering. Possible differences between intrapersonal attributions and interpersonal attributions for littering of others will be specifically investigated. Based on previous theories and findings, it is expected that this investigation will reveal a self-serving tendency in laypersons' evaluations of causes of their own littering which protects the self from self-blame and social blame ( $\approx$ justification). By including an investigation of the evaluation of the behaviour of others, the MJB is embedded into a broader network of social processes and relationships in this study (see upper part of Figure 1). Complementary to the evaluation and justification of their own behaviour, people also evaluate behaviour of others and either put blame on them or justify their actions. Behavioural decision-making, thus, involves internal justifications and is likewise related to social evaluation and influence processes based on interpersonal attributions.

\section{Materials and methods}

\section{Data acquisition and experimental embedding of the survey}

A questionnaire-based survey was conducted to investigate and compare subjective causal attributions of people for their own littering and littering of others. The participants of the study were recruited in public places of various Swiss cities. Passers-by were asked to participate in a survey on littering, and if they agreed, they were handed out questionnaires in self-addressed post-paid envelopes. The questions investigating causal attributions for littering (which are focused in this article) were embedded in a larger questionnaire developed for a quasi-experimental study on anti-littering communication, in which effects of posters and face-toface communication on littering intentions for the future were investigated. The experimental design and its findings have been published by Hansmann and Steimer (2015) and will, therefore, not be reported here. However, due to the experimental variation, half of the persons who received a questionnaire were engaged for about 5 minutes in a face-to-face communication on the topic of littering before completing the questionnaire. The possible influence of these face-to-face communications on causal attributions for littering is not the main focus of this article and no a priori hypotheses were formulated in this regard. However, since causes of littering may have been addressed in the face-to-face discussions, a corresponding analysis will be accomplished to control for a possible influence. Furthermore, all participants of this study evaluated 3 anti-littering posters displayed in the questionnaire. None of these posters addressed or mentioned causal attributions for littering (cf. Hansmann and Steimer, 2015, 2016), and their influence on such attributions is, therefore, presumably negligible. However, the embedding of the present study and findings in a surrounding study on anti-littering communication requires caution in the interpretation of the findings. As the present study is the first one to investigate causal attributions for littering, it is important that future studies aiming to replicate the findings and investigate causal attributions for littering in more depth will be conducted.

\section{Content of the questionnaire}

The first items of the questionnaire asked for age and gender of the participants. Subsequently, some items, which are not focused in this article, followed. The participants evaluated 3 anti-littering posters depicted in the questionnaire, and those who took part in face-toface communications on littering additionally evaluated these face-to-face talks (Hansmann and Steimer, 2015, 2016). Further items asked, which are likewise not focused in this analysis, addressed attitudes towards littering and intentions for future behaviour.

Thereafter, 3 items on subjective reasons for one's own (possible) littering and for littering of others were included in the questionnaire. Firstly, the participants were asked to report the frequency of their possible own littering behaviour in the past on a 5 -point rating scale $(1=$ never, $2=$ seldom, $3=$ sometimes, $4=$ often, $5=$ very often). Secondly, they were asked for the reasons why they littered in the past, if they did so. This question was open-ended and left space to describe one or several 
reasons for one's own littering. People who did not litter in the past (responding never to the previous question) were not expected to answer this question. Thirdly, all the participants were asked why they think some other people litter waste. Again, the question was open-ended and space was provided to describe one or several reasons for littering of other persons.

\section{Statistical analysis and hypotheses}

Subjective attributions for one's own littering and littering by others were extracted from the open-ended responses of the participants. In the first step, 15 rather specific categories of reasons for littering to which the attributions could be assigned were formed. The responses of the participants contained one or several of the 15 distinct attributions for littering. These specific categories of attributions were only analysed in a descriptive way. Based on a combined data- and theory-driven approach, the 15 different causal attributions for one's own littering and littering by others were then assigned to 6 higher order categories to establish sufficient numbers of entries for statistical analyses with adequate power. To compare intrapersonal and interpersonal attributions with regard to the frequency of occurrence of attributions of these categories, six separate 4-field chi-square tests were conducted.

Littering is a negative, norm-violating behaviour. Personal attributions make the litterers responsible for this behaviour and are, thus, putting blame on them, whereas situational attributions protect the actor from being blamed and may, thus, be regarded as justifications for littering. Based on previous empirical findings and theoretical accounts on justifications and attributions as outlined in the introduction, it was expected that there would be more situational attributions for one's own littering than for littering of others (Hypothesis 1). Additionally, it was expected that there would be less personal attributions for one's own littering than for littering by others (Hypothesis 2).

Differences between the two experimental conditions (with vs. without face-to-face communication), between men and women, and between younger and older people were also investigated using 4-field chi-square tests, but separately for intrapersonal and interpersonal attributions. No theory-based a priori hypotheses were formulated with regard to these comparisons.

\section{Participants}

Altogether 420 questionnaires were distributed, 210 in each quasi-experimental condition. In total, 147 questionnaires were filled out and sent back in enclosed return envelopes (response rate 35\%). The participants included 82 persons (56\%) who participated in face-toface communication on littering and 65 persons (44\%) of the control condition without face-to-face talks. The gender distribution was $64 \%$ women and $36 \%$ men. This gender distribution deviates highly significantly from an equal distribution (binomial test, assumed test proportion 50:50, $p \leq 0.001$ ) and women are, thus, overrepresented in this study. The age of the participants ranged from 15 to 86 years with an average of $M=33.4$ years $(S D=17.7$ years, median $=26$ years, mode $=18$ years $)$.

\section{Results and discussion}

\section{Self-reported frequency of littering}

The participants judged the frequency of their own littering in the past on a rating scale from 1 (= never) to 5 (= very often). The overall mean of the ratings was $M=2.0$ corresponding to the answer rarely (=2). Almost $30 \%$ of the respondents said they never littered waste in the past, $42.9 \%$ selected rarely, almost 25\% responded with occasionally and only $2.7 \%$ stated that they littered often in the past. Not a single person selected very often. Men reported somewhat more littering $(M=2.2)$ than women $(M=1.9)$, but this difference was not significant (independent samples t test, $p=0.075$ ). Self-reported littering decreased significantly with the age of the respondents (Pearson correlation: age with self-reported littering, $r=-0.33, p<0.001)$.

\section{Stated reasons for littering by oneself and others}

Of the 146 participants, 131 (89.7\%) provided reasons for the littering of others and 78 (53.4\%) provided reasons for their own littering in the past. The question asking for an interpersonal attribution for littering by others was, thus, answered more often than the one asking for an intrapersonal attribution. This was to be expected, as some people stated they never littered in the past.

In the first step of content analysis, the diverse specific answers were assigned to more general categories to establish sufficient numbers of entries for statistical testing. 
The answers were, thus, assigned to 6 main categories following the assignment scheme described in Table 1. The last column of the scheme classifies these attributions as internal (i.e., blaming the actor) or situational (external, justification). It also considers that personal attributions vary in the degree of blame put on the actor as, for example, inattentiveness contains elements of an excuse (the act was not performed intentionally) as well as of an accusation, whereas ignorance, naivety and convenience assign more responsibility to the actor. On the contrary, if "overfilled disposal waste bins" are provided as the reason for littering, the negative behaviour has been attributed to aspects of infrastructure. The category infrastructure represents an external, situational attribution serving as justification for the actor.

The response of a participant may contain one or more attributions or causal explanations. However, the responses were coded in a way to ensure that each person's response can maximally have the value of one (= type of attribution present) for each higher order category of Table 1. This means that, for example, attributions of a person to two (or more) aspects of infrastructure such as "waste bins were overfilled" and "waste bin was far away" are counted identically as the response of a person who noted only one of these two reasons.
The percentage distribution of intrapersonal and interpersonal attributions for littering after classification based on the 6 different categories is shown in Figure 2. Accordingly, problems with the disposal infrastructure are considered the most common reasons for one's own littering (97.4\%), but are rarely mentioned as the reason causing others to litter (19.1\%). The relative frequency of intrapersonal and interpersonal attributions to infrastructure was compared by means of a 4-field chi-square test, which revealed that this difference was statistically highly significant $\left(X^{2}=120.19 ; d f=1 ; p<\right.$ 0.001). Significant differences were also found for the 3 attribution categories ignorance $\left(11.5 \%\right.$ vs. $87.0 \%, X^{2}=$ $115.03, d f=1, p<0.001)$, convenience ( $29.5 \%$ vs. $55.0 \%$, $\left.X^{2}=12.8, d f=1, p<0.001\right)$ and naivety ( $0 \%$ vs. $55.7 \%$, $X^{2}=66.8, d f=1, p<0.001$ ), which were used significantly more often to explain littering of others than one's own littering. Hypotheses 1 and 2 were confirmed by these findings in relation to these categories.

However, attributions belonging to the two remaining categories inattentiveness and conformity with norms were found roughly with the same relative frequency as explanations for one's own littering and littering by others (all three chi-square tests, $p>0.05$; for percentages see Figure 2).

\section{Table 1}

Scheme for the assignment of perceived reasons for littering to 6 higher order categories of attributions

\begin{tabular}{|c|c|c|}
\hline Specific perceived reasons for littering & Higher order category & Attribution characteristics \\
\hline 1 & 2 & 3 \\
\hline $\begin{array}{l}\text { No disposal facilities/waste bin(s), not enough waste } \\
\text { bins, overfilled waste bin(s), waste bin too far away }\end{array}$ & Infrastructure & $\begin{array}{l}\text { Situational (physical), } \\
\text { justification }\end{array}$ \\
\hline Laziness, too lazy, convenience & Convenience & Personal, accusation \\
\hline $\begin{array}{l}\text { Inattention, by accident, inadvertently, due to time } \\
\text { pressure/stress }\end{array}$ & Inattentiveness & $\begin{array}{l}\text { Personal, justification or } \\
\text { accusation }\end{array}$ \\
\hline $\begin{array}{l}\text { To appear "cool", peer pressure, location } \\
\text { is anyway dirty }\end{array}$ & $\begin{array}{l}\text { Conformity with negative / dysfunctional } \\
\text { descriptive or prescriptive social norms }\end{array}$ & $\begin{array}{l}\text { Situational (social), } \\
\text { justification or accusation }\end{array}$ \\
\hline $\begin{array}{l}\text { Indifference, no respect for others, location will be } \\
\text { cleaned again/anyway }\end{array}$ & Ignorance & Personal, accusation \\
\hline Lack of knowledge, being uneducated & Naivety & Personal, accusation \\
\hline
\end{tabular}

Note. If a participant has noted various specific reasons from the same higher order category, these are counted together as one. The higher order categories are, thus, coded dichotomously as 0 (= category of attribution not present) or 1 (= category of attribution present) 
Fig. 2

Percentage of respondents providing reasons belonging to 6 categories of reasons for their own littering (self-attribution, $N=78$ ) and for littering by other people (interpersonal attribution $N=131)$ *** $p<0.001$ significant difference according to the chisquare test

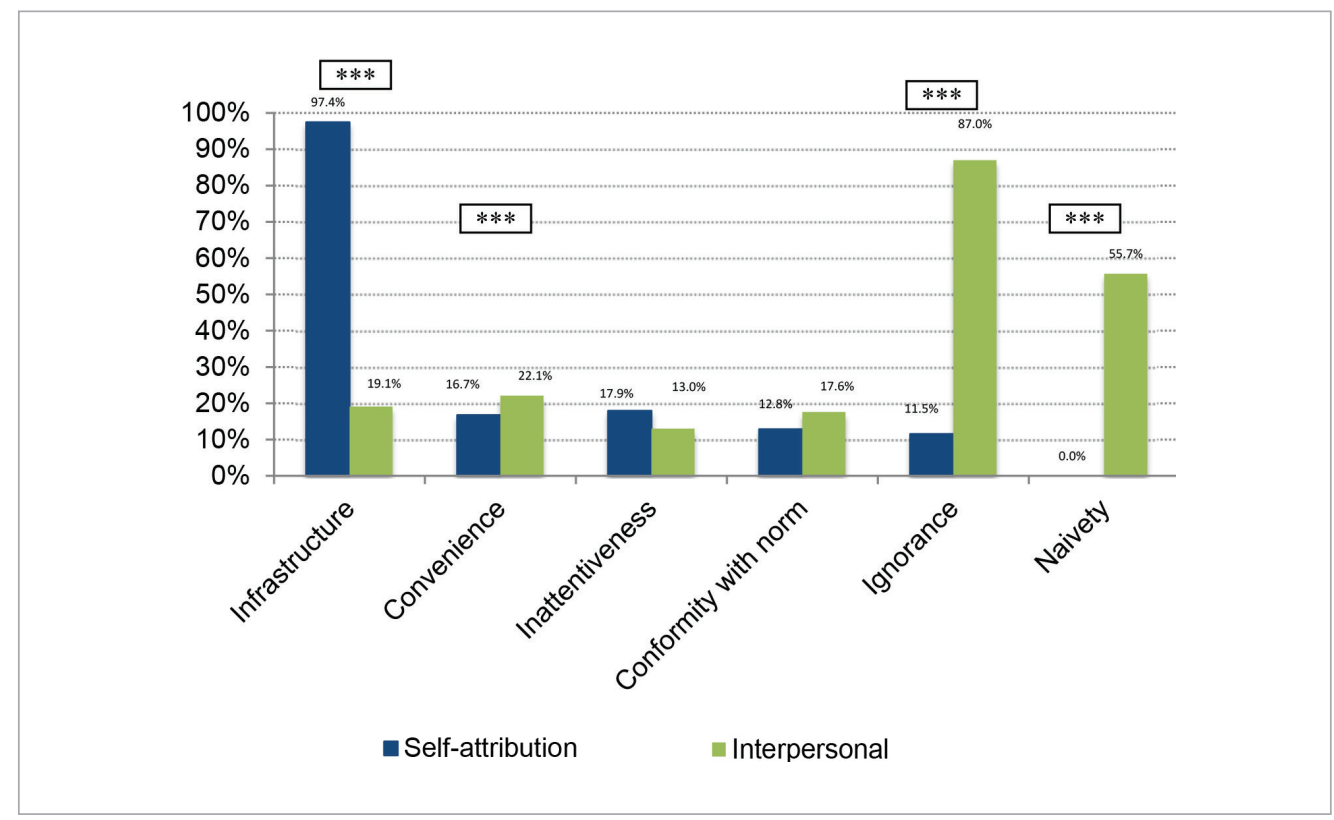

\section{Influences of demographic variables on attributions for littering by oneself and others}

For the analysis of possible gender differences in causal attributions, intrapersonal and interpersonal attributions of the 6 categories were compared between men and women. For this purpose, in total, 12 chi-square tests were conducted. No significant differences between the two genders with regard to the perceived reasons for one's own littering and littering of other persons were found in these comparisons. The relative frequencies of the 6 categories were similar across genders for both the intra- and interpersonal attributions.

To analyse a possible influence of the age of the participants on the attributions, the sample was split in two age groups, namely persons who are younger or exactly 25 years old and persons who are 26 years or older. The analyses by means of the chi-square test showed no significant differences in the perceived reasons for one's own littering. However, in 2 of the 6 chi-square tests with respect to reasons why other persons supposedly litter, significant differences were found. Younger participants mentioned reasons of the category infrastructure significantly more often to explain littering by others than older participants $\left(29.0 \%\right.$ vs. $10.1 \%, X^{2}=7.5$; $d f=1 ; p<0.01)$. On the contrary, attributions to naivety were provided by $69.6 \%$ of the older respondents but only by $40.3 \%$ of those younger or exactly 25 years old, which also represents a significant difference $\left(X^{2}=11.3\right.$; $d f=1 ; p<0.001)$. The elders accordingly look upon other persons who litter, rather as (possibly younger and) naive, while the younger regard critical points of the infrastructure more often as cause of littering.

\section{Quasi-experimental condition and attributions for littering}

Attributions of respondents who participated in face-toface communication with anti-littering ambassadors (experimental condition) were compared with attributions provided by those who did not take part in such talks (control condition). The corresponding 4-field chisquare tests on intrapersonal attributions showed no significant differences between the two conditions with regard to any of the higher order categories. Attributions for one's own littering were, thus, not influenced by the face-to-face conversations with the anti-littering ambassadors. However, considering attributions for the littering of others, significant differences were detected with respect to 4 categories of attributions.

As Figure 3 shows, the respondents who did not participate in a face-to-face discussion attributed littering of others significantly more often to naivety $(69.4 \%$ vs. $\left.43.5 \% ; X^{2}=8.86 ; d f=1 ; p<0.01\right)$ and conformity with 


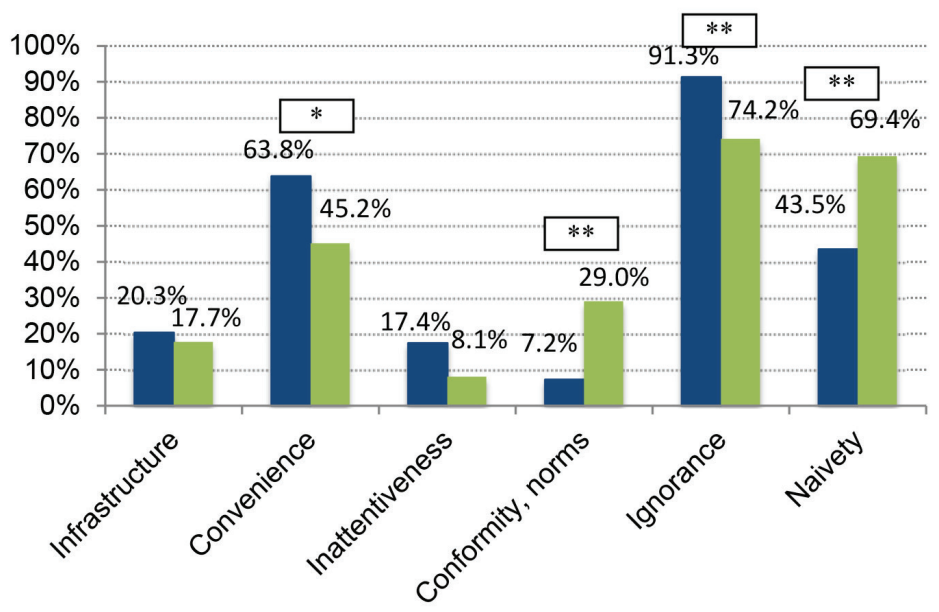

Fig. 3

Percentage of respondents with anti-littering faceto-face discussion $(N=69)$ and without face-to-face discussion $(N=62)$ providing attributions of 6 categories for littering of other persons; ${ }^{*} p<0.05$; ${ }^{* *} \mathrm{p}<0.01$, significant difference according to chi-square tests (wrong) norms (29.0\% vs. $7.2 \% ; X^{2}=10.71, d f=1, p=$ 0.001 ) as compared with the persons who participated in such discussions. On the contrary those who participated in face-to-face discussions on littering attributed littering of others more often to ignorance $(91.3 \%$ vs. $\left.74.2 \% ; X^{2}=6.84 ; d f=1 ; p<0.01\right)$ and convenience $(63.8 \%$ vs. $\left.45.2 \% ; X^{2}=4.57 ; d f=1 ; p<0.05\right)$ as compared with the people from the control condition.

Subjective reasons for one's own littering were, thus, not influenced by the face-to-face discussions, but they had a considerable influence on attributions for the littering of others. The greater stability of self-attributions as compared with interpersonal ones may be due to the higher level of knowledge and insight that people have regarding their own behaviour as compared with behaviour of others (Aronson et al., 2003, Jones at al., 1972). It seems plausible that people are not so easily influenced with respect to their beliefs on causes of their own (littering) behaviour as they consider themselves knowing in this regard, whereas they may consider anti-littering ambassadors as experts for littering in general and, therefore, may nevertheless adopt reasons which the ambassadors state for littering in general, respectively by others.

In spite of this difference, both the participants who took part in face-to-face discussions as well as those from the control condition consider the negative personal attributions ignorance, naivety and convenience as the 3 predominant reasons for other people's littering (Figure 3). The fundamental finding of a prevalence of negative personal attributions for littering of others was, thus, not altered by the experimental variation included in this study. There was no significant influence of the experimental variation on causal attributions for one's own littering. The finding of a prevalence of situational, infrastructure-based accounts (as justification) for one's own littering was likewise not altered by the experimental variation.

\section{Conclusions}

The reasons which people hold responsible for their own littering and for other people's littering were investigated and compared. People attributed their own littering rather to external situational factors, whereas littering by others was predominantly attributed to negative internal, personal factors. The majority of litterers (97.4\%), thus, excused their own littering with dysfunctional aspects of the disposal infrastructure such as lacking or overfilled waste bins whereas only 19.1\% of the participants make these aspects responsible for 
other people's littering. Within the frame of the MJB, this tendency can be understood as a process of justification in which litterers protect themselves from selfblame and from being blamed by others by renouncing personal responsibility for their negative dysfunctional behaviour. On the contrary, other people's littering was predominantly explained by personal factors, in particular ignorance followed by naivety and convenience. In line with previous research, situational, external factors were, thus, made accountable to a higher degree for one's own behaviour than for the behaviours of others (Jones at al., 1972, Meyer and Försterling, 1993, Watson, 1982). More specifically, the current findings are consistent with previous studies showing a self-serving bias in attributions (McFarland and Ross, 1982, Kelley and Michela, 1980, Watson, 1982) and suggest that this bias facilitates situation-based explanations for environmentally harmful, norm-violating behaviours such as littering.

Previous attribution research shows that differences between intrapersonal and interpersonal attributions are caused by both motivational and informational factors (Meyer and Försterling, 1993). From the motivational perspective, a self-serving attribution bias protects the self from negative effects connected to self-blame (Campbell and Sedikides, 1999). However, differences in perspectives and knowledge likewise contribute to differences of attributions provided by observers as compared with actors (Jones at al., 1972). People have a different perceptual perspective on their own behaviour, where they usually look upon the situation surrounding them while acting, as compared with the observation of the behaviour of others whom they may perceive as actors in the foreground in a situation that constitutes the background of action. People also tend to know more about the situational constraints and circumstances of their own actions as compared with the situational constraints of other persons.

Accordingly, actor-observer differences in causal attributions are not exclusively due to motivational factors, such as self-serving interests. Still, in line with the $\mathrm{MJB}$, neutralization theory and previous research on a self-serving bias in causal attribution, the present findings suggest a substantial bias through cognitive processes of justification of one's own negative behaviours by claiming situational causation.
Furthermore, personal attributions for morally wrong behaviour of others may serve a social function to influence others in direction of morally positive behaviour by putting blame personally on them. Based on this reasoning, the MJB could, thus, be further elaborated by processes of interpersonal attributions referring to the behaviour of others. Evaluations of others are, thus, conducted complementary to the evaluation and appraisal of one's own behaviour (Figure 1). While the process of evaluating others may be biased towards putting the blame on them, a bias towards self-enhancing justifications may prevail in intrapersonal attributions for one's own littering. The MJB basically represents a social psychological model of environmental behavioural decision-making of individuals embedded in their social context. Through including a focus on attributions, which individuals provide for the behaviour of others, an additional element of social connectivity between behavioural decision-makers and their social environment is established (Figure 1).

Though justifications of litterers seem influenced by a self-protecting bias, they must not be considered straightforwardly invalid. Instead, they may to some extent point to dysfunctional aspects of environmental management and design which may facilitate littering. Lack of disposal facilities or large distances to such facilities have been shown in previous research to increase tendencies of littering (Crabb, 2014, Durdan et al., 1985, Keenan, 1996). The situational attributions for one's own littering are, thus, consistent with previous findings on factors facilitating littering and can be clearly linked to corresponding recommendations for environmental management, namely to provide sufficient and visible disposing facilities in areas where littering is a problem (Baltes and Hayward, 1976, O'Neill et al., 1980, Stokols and Altman, 1987). However, complementary to these implications for environmental management, the partly biased situational attributions have implications for environmental communication and education, namely that corresponding campaigns or activities should help counteract cognitive justifications for littering in order to reduce it (Diekmann and Preisendörfer, 1992; Fritsche, 1999; Hansmann et al., 2006).

The MJB describes diverse factors which influence individual behaviour. As the different approaches or measures that can be applied against littering vary in the 
potential which they have to address certain causes and processes that facilitate littering, the MJB, thus, implies that a broad set of diverse and complementary measures as well educational and campaigning activities are needed to effectively solve the problem of littering. For example, logistic measures (e.g., providing sufficient and visible waste bins) can create behavioural options and reduce restrictions for correct disposal (Baltes and Hayward, 1976, Durdan et al., 1985, Keenan, 1996, Stokols and Altman, 1987). Cleaning up the environment regularly may alter perceived descriptive norms with corresponding implications for perceived prescriptive social norms requiring correct disposal (Cialdini et al., 1990, Reno et al., 1993, Schultz et al., 2013), faceto-face communication, waste education in school and anti-littering campaigns employing media (e.g., posters or TV-spots) may promote environmental knowledge and foster positive personal attitudes (Hansmann and

\section{References}

Ajzen, I. (1991) The theory of planned behavior. Organizational Behavior and Human Decision Processes 50: 179-211. http:// dx.doi.org/10.1016/0749-5978(91)90020-T

Aronson, E., Wilson, T.D. and Akert, R.M. (2003) Social Psychology. Upper Saddle River, NJ: Prentice Hall.

Armitage, C.J. and Conner, M. (2001) Efficacy of the theory of planned behaviour: A meta-analytic review. British Journal of Social Psychology 40: 471-499. http://dx.doi. org/10.1348/014466601164939

Baltes, M.M. and Hayward, S.C. (1976) Application and evaluation of strategies to reduce pollution: Behavioral control of littering in a football stadium. Journal of Applied Psychology 61: 501-506. http://dx.doi.org/10.1037/00219010.61.4.501

Cialdini, R.B., Reno, R.R. and Kallgren, C.A. (1990) A focus theory of normative conduct: Recycling the concept of norms to reduce littering in public places. Journal of Personality and Social Psychology 58(6): 1015-1026. http://dx.doi. org/10.1037/0022-3514.58.6.1015

Campbell, W.K.C. and Sedikides, C. (1999) Self-threat magnifies the self-serving bias: A meta-analytic integration. Review of General Psychology 3(1): 23-43. http://dx.doi. org/10.1037/1089-2680.3.1.23

Copes, H. (2003) Societal attachments, offending frequency, and techniques of neutralization. Deviant Behav-
Steimer, 2015, 2016, Reich and Robertson, 1979). Group processes and resulting group norms may be tackled by well-motivated and positively experienced clean-up activities of social groups (e.g., clean-up days of school classes or sports clubs out in nature). To combine diverse measures and educational activities is, therefore, most promising in reducing littering effectively. The MJB could, thus, be used as a tool for the planning of anti-littering campaigns as it conceptualises the diverse underlying factors that sustain the littering problem (Hansmann, 2012). Still more research is needed to analyse which measures and activities are most suitable to specifically address the different determinants of behaviour.

\section{Acknowledgements}

This research was supported by funding from the Swiss Federal Office for the Environment (FOEN).

ior: An Interdisciplinary Journal 24: 101-127. http://dx.doi. org/10.1080/01639620390117200

Costello, B.J. (2000) Techniques of neutralization and self-esteem: a critical test of social control and neutralization theory. Deviant Behavior: An Interdisciplinary Journal 21: 307-329. http://dx.doi.org/10.1080/016396200404113

Crabb, P.B. (2014) Some things are just made to be littered. International Journal of Social Ecology and Sustainable Development 5(3): 39-47. http://dx.doi.org/10.4018/ ijsesd.2014070104

de Kort, Y.A.W., McCalley, L.T. and Midden, C.J.H. (2008) Persuasive Trash Cans: Activation of Littering Norms by Design. Environment and Behavior 40(6): 870-891. http://dx.doi. org/10.1177/0013916507311035

Diekmann, A. and Preisendörfer, P. (1992) Persönliches Umweltverhalten. Diskrepanzen zwischen Anspruch und Wirklichkeit. Kölner Zeitschrift für Soziologie und Sozialpsychologie 44(2): 226-251.

Durdan, C.A., Reeder, G.D. and Hecht, P.R. (1985) Litter in a university cafeteria: Demographic data and the use of prompts as an intervention strategy. Environment and Behavior 17: $387-$ 404. http://dx.doi.org/10.1177/0013916585173007

Festinger, L. (1954) A Theory of Social Comparison Processes. Human Relations 7: 117-140. http://dx.doi.org/10. $1177 / 001872675400700202$ 
Fritsche, I. (1999) Die Erhebung von Rechtfertigungen umweltschädigenden Verhaltens: Eine experimentelle Studie zur Validität der Fragebogentechnik. Umweltpsychologie 3(1): 68-80.

Hansmann, R. (2012) Erfolgreiche Kampagnen gegen Littering. Umwelt Perspektiven 3/2012: 11-13.

Hansmann R., Bernasconi P., Smieszek T., Loukopoulos P. and Scholz R.W. (2006) Justifications and self-organization as determinants of recycling behavior: the case of used batteries. Resources, Conservation and Recycling 47: 133-159. http:// dx.doi.org/10.1016/j.resconrec.2008.12.003

Hansmann, R., Knoll, V. and Steimer, N. (2015) Welche Ansprache durch Plakate kommt bei Jugendlichen an? - Eine empirische Analyse zur Umweltkommunikation gegen Littering. Umweltpsychologie, 19(2): 124-144.

Hansmann, R. and Scholz, R.W. (2003) A two step strategy for reducing littering behavior in a cinema. Environment and Behavior 35: 752-762. http://dx.doi.org/10.1177/0013916503254755

Hansmann, R. and Steimer, N. (2015) Linking an Integrative Behavior Model to elements of environmental campaigns: An analysis of face-to-face communication and posters against littering. Sustainability 7: 6937-6956. http://dx.doi. org/10.3390/su7066937

Hansmann, R. and Steimer, N. (2016) A field experiment on behavioural effects of humorous, environmentally oriented and authoritarian posters against littering. Journal of Environmental Research, Engineering and Management 72(1): 35-44. http://dx.doi.org/10.5755/j01.erem.72.1.14974

Heider, F. (1958) The psychology of interpersonal relations. New York: Wiley. https://doi.org/10.1037/10628-000

Horsley, A.D. (1988) The unintended effects of a posted sign on littering attitudes and stated intentions. Journal of Environmental Education 19(3): 10-14. http://dx.doi.org/10.1080/009 58964.1988.9942757

Jones, E.E., Kannouse, D.E., Kelley, H.H., Nisbett, R.E., Valins, S. and Weiner, B. (Eds.) (1972) Attribution: Perceiving the Causes of Behavior. Morristown, NJ: General Learning Press.

Keenan, M. (1996) The A, B, C of litter control. The Irish Journal of Psychology 17(4): 327-339. http://dx.doi.org/10.1080/0303 3910.1996.10558119

Kelley, H.H. (1973) The process of causal attribution. American Psychologist 28: 107-128. http://dx.doi.org/10.1037/ h0034225

Larson, J.R. (1977) Evidence for a self-serving bias in the attribution of causality. Journal of Personality 45(3): 430-441. doi:10.1111/j.1467-6494.1977.tb00162.x
Malle, B.F. (2006) The actor-observer asymmetry in attribution: A surprising meta-analysis. Psychological Bulletin 132(6): 895-919. http://dx.doi.org/10.1037/00332909.132.6.895

McFarland, C. and Ross, M. (1982) Impact of causal attributions on affective reactions to success and failure. Journal of Personality and Social Psychology 43(5): 937-946. http://dx. doi.org/10.1037/0022-3514.43.5.937

Meyer, W.U. and Försterling, F. (1993) Die Attributionstheorie. In D. Frey and M. Irle (Eds.), Theorien der Sozialpsychologie. Band I, pp. 175 - 214. Bern: Huber.

O'Neill, G.W., Blanck, L.S. and Joyner, M.A. (1980) The use of stimulus control over littering in a natural setting. Journal of Applied Behavior Analysis 13(2): 379-381.

Reno, R.R., Cialdini, R.B. and Kallgren, C.A. (1993) The transsituational influence of social norms. Journal of Personality and Social Psychology 64(1): 104-112. http://dx.doi. org/10.1037/0022-3514.64.1.104

Reich, J.W. and Robertson, J.L. (1979) Reactance and norm appeal in anti-littering messages. Journal of Applied Social Psychology 9(1): 91-101. http://dx.doi. org/10.1111/j.1559-1816.1979.tb00796.x

Reiter, S.M. and Samuel, W. (1980) Littering as a function of prior litter and the presence or absence of prohibitive signs. Journal of Applied Social Psychology 10(1): 45-55. http://dx. doi.org/10.1111/j.1559-1816.1980.tb00692.x

Schahn J., Dinger J. and Bohner G. (1995) Rationalisierungen und Neutralisationen als Rechtfertigungsstategien: Ein Vergleich zwischen Umwelt- und Delinquenzbereich. Zeitschrift für Differentielle und Diagnostische Psychologie 16(3): 177-194.

Schultz, P.W., Bator. R.J., Brown Large, L., Bruni, C.M., Tabanico, J.J. (2013) Littering in context: Personal and environmental predictors of littering behavior. Environment and Behavior 45(1): 35-59. http://dx.doi.org 10.1177/0013916511412179

Stokols, D. and Altman, I. (Eds.) (1987) Handbook of environmental psychology (Vols. 1-2). New York: John Wiley.

Sykes G.M. and Matza D. (1957) Techniques of neutralization: a theory of delinquency. American Sociological Review 22(6): 664-670. http://dx.doi.org/10.2307/2089195

Watson, D. (1982) The actor and the observer: How are their perceptions of causality divergent? Psychological Bulletin 92(3): 682-700. http://dx.doi.org/10.1037/00332909.92.3.682 


\section{Subjektyvios šiukšlinimo priežastys: savanaudiško šališkumo pagrindimas naudojant integruotą pagrįsto elgesio modelį}

\section{Ralph Hansmann}

Šveicarijos federalinis technologijos institutas, Aplinkosaugos sistemu mokslo katedra, Ciurichas, Šveicarija

\section{Nora Steimer}

Švarios aplinkos grupè (IGSU (“IG saubere Umwelt”)) Ciurichas, Šveicarija

Šiame darbe tiriamos subjektyvios šiukšlių mètymo priežastys, naudojant apklausą $(N=147)$. Dalyviai buvo apklausti, ar praeityje jie šiukšlindavo, o jei taip, kodèl, ir taip pat buvo klausiama, kodèl jie mano, kodèl kiti žmonès šiukšlina viešose vietose. $71 \%$ apklausos dalyviu prisipažino, kad praeityje jie buvo atsikratydavo šiukšlių neleistinose vietose. Šiukšlinimo priežasčių analizè parodè, reikšmingus skirtumus tarp priežasčių, kurias nurode dalyviai kodèl jie patys šiukšlina ir kodèl šiukšlina, jų nuomone, kiti. Nustatyti skirtumai patvirtino ankstesnio tyrimo rezultatus, rodančius savanaudiško šališkumo tendenciją, kalbant apie savo šiukšlinimo priežastis. Savo šiukšlinimo priežastys dažniausia "pateisinamos", pavyzdžiui, trūksta infrastruktūros, perpildyti šiukšlių konteineriai, talpos, o neigiamos asmeninès priežastys, kaip savanaudiškumas, naivumas, ignoravimas, nežinojimas apie šiukšlinimo pasekmès yra priskiriamos kitiems. Išvados analizuojamos atsižvelgiant i integruotą pagristo elgesio modeli (angl. Model of Justified Behaviour MJB) (Hansmann ir Steimer, 2015), kuriame aptariami ivairūs veiksniai, iskaitant požiūrị, normas, žinias, apribojimus ir pasirinkimas, ipročiu formavimąsi ir jvertinimo procesus, kaip pagrindinius veiksnius elgesio sprendimo priemimui. Atsižvelgiant ị rezultatus aptariamos galimos aplinkos apsaugos vadybos priemonių, aplinkosauginio švietimo formavimo, kampaniju „prieš šiukšlinimą“ reikšmè.

Raktiniai žodžiai: šiukšlinimas, savanaudiškas šališkumas, priskyrimas, pagrindimas, iprotis, elgesio modelis 